\title{
EU Agencies' Involvement in Transboundary Crisis Response: Supporting Efforts or Leading Coordination?
}

\author{
Jacint Jordana \\ for European Studies, SciencesPo \\ Juan Carlos Triviño-Salazar \\ Institut Barcelona d'Estudis Internacionals (IBEI)

\section{Correspodence to:} \\ Juan Carlos Triviño-Salazar \\ Institut Barcelona d'Estudis Internacionals \\ Campus de la Ciutadella (Universitat Pompeu Fabra) \\ C. Ramon Trias Fargas, 25-27 • 08005 Barcelona (Spain) \\ E.mail: jctrivino@ibei.org
}

Universitat Pompeu Fabra; Institut Barcelona d'Estudis Internacionals (IBEI); Centre

This is the accepted version of the paper. The published version is: Jordana, J. and Triviño-Salazar, J.C. (2020). "EU agencies' involvement in transboundary crisis response: Supporting efforts or leading coordination?” Public Administration. 1-15. (C) The Authors 2020. DOI: https://doi.org/10.1111/padm.12652 


\begin{abstract}
EU agencies have emerged as entities offering technical coordination to member states and support to the European Commission in different policy areas. Their expertise may play a role in responding to unexpected crises. Against this backdrop, we examine under which circumstances EU agencies, through their specialised expertise, are involved in transboundary crisis responses, and when they acquire a leading position in coordinating those responses. To do so, we study four agencies which faced crises: the EBA and the 2012 banking crisis; the ECDC and the 2014 Ebola outbreak; EFSA and the 2011 E. coli outbreak; and Frontex and the 2015 refugee crisis. Our findings discuss to what extent agencies' involvement in transboundary crises is related to functional (sector characteristics) and institutional (delegation of authority) variables. We also identify that under certain political conditions EU agencies' coordination capability is activated, allowing them to emerge as leading institutions in transboundary crises resolution.
\end{abstract}

\title{
Keywords
}

Coordination capacities, EU agencies, Transboundary crisis, European Union 


\section{Introduction}

Transboundary crises (TBCs) can be defined as those threats that require urgent action and cross geographical, political, economic, social and legal boundaries (Ansell et al. 2010). Since its inception, the EU has faced multiple TBCs of different natures and intensities. Episodes such as the 2010 Icelandic volcano ash cloud, the 2012 European debt crisis or the 2015 immigration flows into Europe illustrate the recurrence of such crises across the EU and the challenges they represent. While numerous monitoring and management mechanisms have been developed by the EU to cope with TBCs (Boin et al. 2014), there is always a shortage of institutions and procedures to facilitate responses to unexpected crisis (Ansell et al. 2010; Boin and Rhinard 2008).

In this environment, it has been argued that, among other purposes, EU agencies may be capable of leading technical responses to TBCs insofar as they manage many crossborder risks that challenge the EU integration process (Eberlein and Grande 2005; Rittberger and Wonka 2013; Jordana and Triviño-Salazar 2019). Their creation from existing networks in specific policy sectors (Levi-Faur 2011; Thatcher and Coen 2008) or as the consequence of previous crises (Coen and Thatcher 2008) has resulted in over 35 EU agencies covering multiple policy domains show. Against this backdrop, here we study the extent to which the specialised expertise of EU agencies allows them to lead the EU response to crises by means of technical coordination of various actors: national regulators, ministries and the Commission. Moreover, in this study we seek to answer the following questions: Under which conditions are EU agencies involved in the response to transboundary crises? When do they exert a leading role in coordinating the response? 
During a TBC, EU agencies may be involved in the response providing their advice, but eventually they may also activate coordination capacities, allowing national, European and global actors to be rapidly deployed in the assessment, information exchange, decision-making and implementation of actions (Egeberg and Trondal 2017; Heims 2016). However, agencies' role can be limited by the member states' vetoes or different EU institutions' competing leadership. We expect agencies’ role -beyond the resources and instruments they have- to depend on various aspects: the institutional rules they are granted and the nature of the sector in which agencies operate. Additionally, we further consider how political configurations -and existing interpretative or distributive conflicts between political and institutional actors- shape agencies' behaviour, facilitating or restraining a leading coordination role by agencies in TBCs.

Our paper answers the proposed research questions by building an analytical framework that examines the involvement of EU agencies in their response to TBCs. Then we introduce a series of case studies of EU agencies which have been present in major TBCs in Europe from 2011 to 2015. Here we focus on how they provided capacities and implemented actions when a TBC emerged in Europe and whether they played a leading role or not in coordinating responses to the crisis. We chose four cases of EU agency involvement in TBCs: the European Banking Authority (EBA) in the 2012 banking crisis; the European Food Safety Agency (EFSA) in the 2011 E. coli outbreak; the European Centre for Disease Control (ECDC) in the 2014 Ebola outbreak in SubSaharan Africa and the extinct European Agency for the Management of Operational Cooperation at the External Borders of the Member States of the EU (Frontex) in the 2015 refugee crisis in the Mediterranean. 


\section{Towards an analytical framework}

EU agencies are specialised, decentralised, non-majoritarian institutions with informative and regulatory tasks in specific policy sectors (Kelemen and Tarrant 2011). The literature on agencies has focused on four broad areas: the creation of EU agencies (Christensen and Nielsen 2010), including after specific crises (Paul 2012; Permanand and Vos 2010); the functional and political motivations behind their design (Coen and Thatcher 2008; Eberlein and Grande 2005; Levi-Faur 2011; Majone 2002; Wonka and Rittberger 2010;); the formal and informal independence from other institutions (Christensen and Laegreid 2006; Groenleer 2009; Trondal and Peters 2013; PérezDurán 2019) and the extent to which they are accountable to their principals (Busuioc and Groenleer 2012; Busuioc 2013). In addition, within the nascent literature focusing on TBC management and the role of EU institutions (Boin and Rhinard 2008; Olsson 2009; Moloney 2010), there are a few studies that examine the role of EU agencies in the European polity (Boin et al. 2014).

The agencification of the EU has meant the delegation of some technical tasks and specialised functions in various policy sectors from the European Commission (EC) or EU member states (Mathieu 2016; Egeberg and Trondal 2017). However, policy responsibility is not fully delegated in EU agencies as far as representatives of EU member states and the EC hold sway on their Management Boards. The nature of EAs' design makes the potential for coordination a key component in their dynamics as they need to align their preferences with other actors' in different policy sectors (c.f. Jordan and Schout 2006).

Under which circumstances whether EU agencies can activate their coordination capacities when a TBC emerges is still a question to answer empirically. This is 
especially relevant since coordination is a complex issue due to the EU's multilevel character and the Commission's small size (Peters and Wright 2001, p. 161). The agencies' concentration of professional capabilities, as well as their EU-wide perspective, can offer coherence when coordinating the response to TBCs in different policy sectors (c.f. Heims 2016; Kettl 2003; Majone 2005). Not only that, EAs may also have the capacity to coordinate responses across different jurisdictions while mobilising actors who may have never worked together (Boin et al. 2014, p.421). EU agencies may be well placed to lead coordination in TBC responses at the European level, as specialised entities with the capacity to implement their technical know-how, identify best responses to the crisis and to activate networks in the policy area. However, agencies may not end up coordinating the response as they remain involved in supporting tasks and crisis responses led by other actors, either at EU or global level.

\section{Developing coordination capacities in response to crises}

We define coordination capacities as those policy-making, regulatory and organisational instruments that are scattered across a network of interdependent actors that when put together can enhance a coherent response to TBCs (cf. Boin et al. 2014; Jordan and Schout, 2006). These instruments allow mobilising financial, technical and human resources, exchanging information and identifying common areas for cooperation while settling potential conflicts among the actors involved in the short term (Jordan and Schout 2006; Rhodes 1997). Putting together these capacities in the response to TBCs implies producing a space that facilitates joint actions where differentiated tasks performed by supranational institutions, member states, third countries and other stakeholders complement each other (see Heims 2016, 2017; Jordan and Schout 2006). 
In any crisis, consistently coordinating different actors becomes a central component in the response's success (Christensen et al. 2016; Kettl 2003;'t Hart, Rosenthal and Kouzmin 1993). If coordination in non-crisis times is hard, under crisis situations it is even more difficult given the multi-actor and multi-level settings in contexts such as the EU (Boin et al. 2014). However, it is precisely in crises where we believe EU agencies can provide a unique coordination role. Due to the nature of the EU's governance architecture, it is clear that EU agencies are not in a situation to implement a hierarchical logic to coordinate crisis responses. Instead, we believe they can become a leading actor based on their technical and specialised character in networks of interdependent actors (cf. Christensen et al. 2016).

A considerable challenge often faced by those actors involved in TBCs episodes is to determine who owns the response and how to act on it (Boin and Rhinard 2008, p.9). In this context, EU agencies are very sensitive to this uncertainty according to their quasiregulatory (agencies with some delegation of authority, capacity to make binding decisions) and non-regulatory (agencies developing operational network activities or just gathering information) functional distinction (Egeberg and Trondal 2011; Wonka and Rittberger 2010). This is particularly the case for agencies without a formal delegation of responsibilities as leading technical coordination in the response may involve acting in a more flexible manner than expected in their mandate.

This paper argues that EU agencies coordinating role around crisis responses occurs when their institutional characteristics, the functional dynamics within the policy sector they operate in and the constellation of actors allow them to do so. In this context, the agencies' possibility of activating an 'orchestrated "surge” of available resources... 
directed to deal with the impact of a rapidly evolving threat' (Boin and Ekengren 2009, p.288) requires coordination beyond the agency itself. The relationship between EU agencies with other actors such as the Commission, the member states and national regulatory agencies (NRAs) may strengthen their involvement in the response (c.f. Christensen and Nielsen 2010). From this involvement, the agency may lead certain aspects related to the coordination of that response. It is precisely in leading relevant actors based on the agencies' technical capacities which may signal their overall ability to offer coherence during crises.

While we understand involvement as the collaborative relationships agencies establish via their technical and specialised expertise during crisis response, leadership refers to the capacity the agency has to become a central coordinating actor as it offers coherence amongst interdependent actors. Based on the intersection of the EU agencification and crisis literatures, we discuss how institutional and functional factors might contribute to explaining the conditions under which EU agencies become involved in crisis response. Next we will concentrate on examining which factors restrain or contribute to expanding EU agencies’ involvement during crises and the extent that such involvement implies assuming a leading role.

We identify the institutional factor to constitute a central element in making sense of the EU agencies' involvement in responding to TBCs. The institutional dimension looks at whether the agencies' legal mandate can be a determining factor in their role during a crisis, assuming discretion in their response to TBCs or at least some autonomy in decision-making. The legal mandate defines the agencies' decision-making capabilities and the instruments and resources they can put into practice to achieve specific goals 
during the crisis (Boin et al. 2014). We expect that wider institutional delegation of responsibilities in the EU agencies will provide them with a prompter and deeper involvement in crisis management, insofar as uncertainty about the agencies' sphere of action declines.

In the functional dimension, our starting point is that actors in a policy sector may feel persuaded to cooperate as the scenario of non-cooperation would imply a high exit cost (based on Schimmelfennig 2018). Crises, as a functional driver, may encourage actors to strengthen the supranational architecture in their respective policy areas; however, they may also guide actors to more intergovernmental responses to avoid spill-over effects when dealing with crises. We expect that the interdependence among actors in a policy sector may facilitate the EU agencies’ involvement as they can obtain resources and use their expertise in the crisis response. To operationalise this dimension, we look at the high or low interdependence among actors in the policy sector in which the EU agency operates when faced with a TBC. Crossing the institutional and functional dimensions provides our projected expectations about the involvement of EAs in TBCs (see table 1 below).

[Table 1 around here]

We consider these expectations as a first step in our analysis. They clarify the circumstances under which EU agencies become involved in TBCs. As a second step, we consider the political dimension and discuss how an agency can coordinate the constellation of actors around a crisis, using its capacities to lead the response. For this purpose, we must identify whether there is agreement or disagreement among the actors 
involved in the response in each policy area. We would like to explore whether the political dimension contributes critically or not to the variation in agency leadership in coordinating crisis responses once we understand the logic of its involvement. Our expectation is that EU agencies emerge as a repository of coordination tools only when political actors across different levels within the EU polity deem agreeing on a common response less politically costly than disagreeing. In this scenario, the agency may find a space to offer guidance. Conversely, when political actors at different levels deem disagreeing on a common response less politically costly than agreeing, EAs will see their role limited to more technical involvement.

\section{Case selection and methods}

To compare our expectations, we elaborated a methodological strategy to assess their explanatory potential. We chose four EU agencies which were involved in the response to major TBCs. Our selection was based on a diverse-case method. This methodology selects two or more cases that vary along relevant dimensions. We sought cases with variation along our institutional and functional dimensions (see table 1). By doing so, we believe that the agencies selected can reflect different types of involvement in a TBC. We ended up with four cases: EBA and its involvement in the 2012 banking crisis; EFSA and its role during the 2011 E. coli outbreak; the ECDC during the 2014 Ebola outbreak and the extinct ${ }^{1}$ Frontex and its involvement in the 2015 refugee crisis.

In the institutional dimension guiding our selection, the EBA has the farthest-reaching mandate. The Authority was born in 2011 as a quasi-regulatory agency. It is part of the European System of Financial Supervision (ESFS) created in response to the 2008

\footnotetext{
${ }^{1}$ In 2016 it was replaced by the European Board and Coast Guard Agency. The new agency has kept the same acronym.
} 
financial crisis (Schimmelfennig 2018). The EBA’s design aimed to reflect the intention of centralising banking supervision practices at the EU level (Martino-Levi 2019). Its overall objective is to maintain the EU's financial stability and to safeguard the integrity, effectiveness and orderly operation of the banking sector (Founding Regulation No. 1093/2010). The EBA can draft binding technical standards, adopt soft law instruments (e.g. guidelines and recommendations) and supervise compliance with EU financial rules (Ferran 2016; Martino-Levi 2019).

Created in 2004, Frontex's mission was 'to ensure the effective management of the external borders by coordinating member states' implementation of relevant EU measures’ (Regulation 2007/2004). The agency had wide legal capabilities to evaluate, approve and coordinate joint operations at the request of the member states, including deploying Rapid Border Intervention Teams (RABIT). The RABIT mechanism provided fast response teams in the form of border control personnel upon the request of a member state facing exceptional migratory pressure (Regulation 2007/2004; Regulation 863/2007).

On the other end, EFSA and the ECDC show narrow legal capabilities as they have informative and risk-assessing functions in food safety and health. Following a series of food crises in Europe (most notably, the BSE mad cow crisis), EFSA was created in 2002 as a European risk-assessing body in the food sector. It produces scientific opinions and advice on food and feed safety mainly in response to requests for scientific advice from the Commission, the European Parliament and member states (General Food Law, Regulation 178/2002). In the case of the ECDC, the agency was created with the mission 'to identify, assess and communicate current and emerging threats to human 
health from communicable diseases' (Regulation (EC) No. 851/2004). The agency is responsible for the Epidemiological Surveillance Network (ESN) and the Early Warning and Response System (EWRS) which is based on scientific and technical data member states submit to the agency.

In relation to the functional dimension, the four agencies selected are placed in different policy sectors with varying degrees of interdependence among the actors involved. In the case of the EBA, the agency operates in the banking sector, a policy area where transnational actors are very much interdependent and must cooperate to tackle potential systemic risks (Gren et al. 2015). Relevant actors in this policy area are the European Central Bank (ECB), EU institutions, the member states' governments, National Competent Authorities (NCAs) ${ }^{2}$ and major Eurozone banks, among others (Gren et al. 2015). On the higher part of the continuum, we also find food safety, the policy area where the EFSA operates. Food safety developed from the desire to protect consumer from potential risks contained in foodstuffs (Permanend and Vos 2010). This area has long been considered a spill-over from the market integration as there has been a hightened interest in regulating foodstuffs from 'the farm to the fork' by EU institutions (Paul 2012). In this regard, the strong interdependence in the ESM has guided food safety as it is an area considered central to the trust consumers have in the implementation of food standards across member states (Permanend and Vos 2010). Relevant actors are EU institutions, the national agencies on food safety, health ministries and the food industry.

On the lower end of the continuum, we find Frontex. The agency navigates the external dimension in the area of Justice and Home Affairs (JHA). The integration process in

\footnotetext{
${ }^{2}$ National authorities responsible for banking supervision. They are either central banks in some member states, in others, a separate regulatory body (Gren et al. 2015, Jordana and Rosas, 2019).
} 
this dimension has been largely dominated by the member states which have left migration and asylum laws in place rarely going beyond common minimum requirements (Chetail et al. 2016; Niemann and Speyer 2017). This situation granted member states important levels of discretion to pursue their own interests (Trauner 2016). Central to the functioning of this policy sector are the member states' interior ministries, national border patrols and EU institutions -especially those related to the area of JHA (Lavenex 2015). When it comes to communicable diseases in the area of health safety, the literature has observed very low interdependence among different actors in Europe. According to Rhinard (2009), this is due to the member states' protective prerogatives which do not facilitate cooperation in operational planning. In fact, Permanend and Vos (2010) state that managing communicable diseases is deemed a purely health safety issue, different from food safety which is linked to the SEM. This difference affects the perceptions of different actors as the exit costs of no cooperation in the former are lower than in the latter. In this policy sector, health ministries, agencies specialised in communicable diseases and EU institutions are central.

When it comes to the TBCs each agency faced, the EBA got involved in the response to the 2012 banking crisis. This crisis emerged when the financial capacity of the so-called Euro-periphery (member states mainly in Southern Europe) was under intense scrutiny as rising sovereign debt increased the risk of default (Gren et al. 2015). The high point of the crisis came when Bankia, the fourth largest Spanish bank, together with some other smaller banks, was nationalised. The Spanish government asked the European Stability Mechanism (ESM) for $€ 100$ billion to keep its banking system afloat in May 2012. Secondly, EFSA got involved in the response to the 2011 E. coli outbreak. The outbreak was detected in Germany and spread to France, the Netherlands, Sweden, 
Denmark and the UK between April and June 2011 with 3,950 infections and 53 fatalities. Finding the origin of the outbreak became the priority as Spanish vegetables had mistakenly been blamed for the crisis. It was later found that Egyptian fenugreek seeds were the carrier. Thirdly, the ECDC got involved in the response to the Ebola outbreak in Sub-Saharan Africa in March 2014. The speed of the contagion produced concern among EU authorities of the potential implications of the arrival of the virus on European soil. The culmination of the crisis came when a Spanish nurse was infected with the virus from treating a repatriated patient in a Madrid hospital in October 2014. Finally, Frontex got involved in the response to the 2015 refugee crisis. This crisis started in 2014 when war in Syria and political and economic instability in the vicinity of the EU produced the highest number of immigrants and refugees in Europe since WWII in 2015 (Trauner 2016). Affected member states were incapable of managing the situation, as EU responses were deemed insufficient in the quest to diminish the flows humanely. Imposing border controls within the Schengen Zone and outsourcing border management to third countries (i.e. Turkey) contributed to decreasing the flows.

Our study primarily relies on archival research based on analysing 85 official documents released by EU agencies and relevant institutions, namely the Commission. These documents helped us understand the legal instruments governing the agencies, the technical discussions around the most suitable response to the crises as well as the overall position the agencies took during these crises. This corpus was comprised of technical reports, press releases and meeting minutes directly related to the selected agencies' involvement in their corresponding crises. We also looked at technical documents released in preparation for potential threats. In addition, we systematized and analysed 693 newspaper articles on the selected crises and the agencies studied. They 
helped to identify the features of the crises, different positions assumed by relevant actors and the overall responses offered. We included articles from newspapers according to their ideological leaning (left-wing, right-wing), readership and quality media outlets. We used the two most important newspapers in each of the countries most affected by the crises as well as the European news outlets with the largest readership among European elites. The information collected from our archival research was completed with 15 semi-structured interviews. The interviews were aimed at key respondents inside the agencies (scientific and managerial positions) and outside them (top ranking officials in different DGs) who were directly involved in the crisis response (Please refer to the appendix for the complete list of interviews).

We followed a deductive thematic coding to analyse the data collected. After doing so, new themes emerged which were coded accordingly. Below we present the findings for each of the selected cases.

\section{Agency involvement in TBCs: unpacking the institutional and functional}

\section{dimensions}

The EBA: 'strong' involvement in the banking crisis

The EBA's inclusion in the overall response to the banking crisis as well as its capacity to make national supervisors comply with its guidelines increased the agency's involvement. In the institutional dimension, the agency’s role was facilitated by a legal mandate that provided it with the ability to obtain information from NCAs. In accordance with its mandate, the agency conducted a recapitalisation exercise in the second half of 2011 to assess sovereign risk in the member states' banking systems. The 
exercise showed that banks in Southern Europe were especially vulnerable to economic shocks. Following the exercise, in December 2011, the agency made what became its most important decision during the banking crisis: a formal recommendation that EU banks increase their capital ratios by June 2012 (EBA 2012). The recommendation was a non-binding instrument with the goal of offering 'consistent, efficient and effective supervisory practices' and 'common, uniform and consistent application of Union law' (EBA Regulation, art. 16.1.). This decision can be framed under the EBA's exercise of regulatory centralisation at the EU level to protect member states against externalities that might affect their economic performance (Martino-Levi 2013). Despite its quasiregulatory role, the agency still had to rely on cooperation from national supervisors to obtain the information for it to evaluate the asset quality of national banking systems (Int. 15).

In the functional dimension, NCAs had a strong incentive to cooperate with the EBA as not doing so could jeopardise the whole Euro-zone banking system. The interdependence of the Euro-zone emerged as a decisive factor in the national authorities' compliance with the EBA's recommendation. Moreover, when different banking systems showed signs of weakness, the EBA was given a central role in designing the respective adjustment programs agreed among European authorities, the IMF, the ECB and the affected countries (e.g. Bulgaria, Cyprus, Greece, Ireland, Portugal and Spain). This was especially evident in the Spanish case as the agency was invited to join the Strategic Coordination Committee and the Expert Coordination Committee (formed by the EC, ECB, IMF and national authorities) that helped design the aid package under the European Stability Mechanism (ESM) and oversee its implementation (EBA, press release, 28 September 2012). 
Frontex: limited involvement in the refugee crisis

Important limitations in its design as well as in its capacity to pool resources to carry out operations left Frontex with limited involvement during the refugee crisis. Under the institutional dimension, Frontex's design granted the agency with a strong legal mandate for risk assessment and operational coordination. In practice the agency's design did not translate into capacity to carry out its mandate during the crisis. In fact, this critical aspect severely hampered its involvement. Although Frontex launched different operations (Triton in Italy, Poseidon in Greece and Sophia in Eastern Europe) at the request of member states under strong migratory pressure (Frontex 2015ab), the founding regulation did not provide the agency with the 'teeth' to pool the resources needed in times of emergency. For instance, once a member state agreed to launch an operation with Frontex, both would assess the resources needed to implement it (e.g. the number of specialist officers and the quantity and type of technical equipment) (Regulation No 863/2007) but the other member states could decide whether to contribute to the operation or not.

The faulty agency design was not the only reason for its limited role. Looking at the functional dimension, the agency was embedded in a policy sector where the preeminence of the nation-state had strongly informed its Europeanisation (Menz 2015). The limited commitment by certain member states to European-led solutions directly affected the agency's capacity to pool key resources in its response. An example of this situation was the replacement of the Italian-led Mare Nostrum operation with the EUled Triton operation in the Central Mediterranean. The latter downgraded the scope and the amount of resources employed to guard the Central Mediterranean route as member 
states not under migratory pressure refused to fund the more effective but expensive Italian operation (Int. 11).

The functional limitation Frontex faced during the crisis 'exposed the weaknesses of the system that had been constructed in the 1990s and had not been sufficiently advanced and Europeanised since' (Niemann and Speyer 2017). The limited role of Frontex in the crisis is the outcome of limited participation from relevant actors (i.e. member states) in response to collective risks. Some scholars point to the agency's structural dependence on the member states' voluntary contributions to operations in a sector so close to the heart of national sovereignty (Niemann and Speyer 2017; Börzel and Risse 2018; Genschel and Jachtenfuchs 2018). As an interviewee told us:

The specific crisis management was very complex to arrange and included a very close coordination of different actors. What was obvious is that there was no... not a common policy, a common procedure, a common idea on how to solve things, and everyone was starting to adopt measures like... (Int. 11). Frontex puts the money, coordinates, agrees, but then if you don't get the tools, if you don't get the assets and the contributions from the member states' authorities, we cannot actually operate (...) (Int. 11).

EFSA: expansive involvement in the E. coli outbreak

The nature of EFSA as a non-regulatory agency with risk-assessing tasks should have limited its involvement in this crisis. However, we see an expansive involvement as the agency acted beyond its established mandate. Looking at the institutional dimension, we identified that the agency initially followed the procedures established in its riskassessment mandate (EFSA 2011b). Yet an official request from the Commission to investigate the origin of the outbreak in the affected member states was a game changer. 
The Commission interpreted the agency's mandate expansively as assisting the Commission in risk-managing activities when needed was stated among its tasks.

When looking at the agency's functional dimension, the interdependence among the different national agencies on food safety, ministries and the food industry in general created a cooperative environment that facilitated its expansive involvement in this crisis. The human and economic losses strengthened the agency's scientific position as EFSA had a strong reputation derived from the knowledge accrued in different food crises (e.g. 2008 Dioxin crisis) (Robinson and Deluycker 2012). One example of its centrality at the EU level is that amidst the outbreak, the agency received an urgent request from German authorities and the Commission in May 2012 to investigate the origin of the E. coli outbreak. The agency responded as per its guidelines by doing an emergency risk-assessment of the affected member states (EFSA 2011c). Earlier risk assessment experience helped the agency activate all the scientific structures to respond to this request (Robinson and Deluycker 2012; Int. 01).

Moreover, the appearance of new cases in France precipitated the EC's request for EFSA to organise a scientific taskforce to investigate the origin of the outbreak in the affected member states. The request became the first risk management operation the agency was ever involved in. The aim was to 'trace back the implicated seeds through the EU supply and distribution chain’ (2011 Annual Report, p. 24). By doing so, the ultimate goal was to implement 'risk-mitigating measures regarding potential further outbreaks' (EFSA 2011a, p. 2). EFSA set up two groups: a technical one in charge of the scientific aspect of the response and a managerial one in charge of providing the resources necessary for the response. The taskforce included specialists from the affected member states, the EC, ECDC, the WHO and the FAO. The expansive 
involvement of the EFSA contributed to providing a solution for the key component of the crisis: discovering the origin of the outbreak (Int. 01, 02; Robinson and Deluycker 2012).

ECDC: weak involvement in the Ebola outbreak

The agency’s involvement during the Ebola crisis was a mixture of routine responses in risk assessment and conflict with the Commission and member states when it attempted to increase its scope.

By looking at the institutional dimension, the ECDC's mandate as an informative, intraEuropean risk-assessment agency with minimal authority over the member states (Grant 2012; Greer 2012) hampered its involvement in this crisis. The ECDC, especially at the beginning of the outbreak at the end of 2013 and the first months of 2014, followed its mandate. During this phase, the agency monitored the situation in Sub-Saharan Africa (2015 Annual Report: 14) and supervised the contingency plans member states had in the event of an outbreak in Europe. The latter task was done under the Ebola virus taskforce set up by the Commission to monitor the situation and secure the preparedness of the member states. The agency's faulty design impeded initiating risk-managing actions on its own. This situation became evident when the WHO and the US Center for Disease Control (CDC) asked the agency to participate in a mission outside the EU, in Guinea. After negotiations with different EU authorities and member states, the ECDC was allowed to organise the mission.

The legal limitation was complemented by functional limitations that hampered the ECDC's role in the Ebola outbreak. The ECDC did not have enough resources to work beyond European borders in an area where pandemics represent global threats. This 
situation can be explained as the agency is embedded within a policy sector with low interdependence in the EU. The low interdependence is due to the fact that 'national laws on pandemic planning (that) are fragmented and inconsistent, complicating a coordinated response to communicable diseases' (Jacobson 2012). In fact, the health authorities from several member states did not provide human resources for the agency to go abroad as they deemed that doing so might leave their countries unprotected from other threats. This situation was summarised by an interviewee:

During the first month our role was clearly to prepare and protect Europe in Europe... carry out risk assessment, ensure the capacity (of member states)...and we did all of that, and that is our role, and the perception was that if we all go to Guinea, who is going to prepare Europe?... Should I protect my house from the fire at my neighbours' before helping them [put it out]? (Int. 07)

Although the ECDC participation in a mission to Africa was eventually authorised by the Commission, the agency encountered practical difficulties as it was not clear what its role in international missions was (Interviews 07, 08, 09). Questions such as who was in command of the mission and who was going, how to organise it or even who was paying the salaries of those participating took time to get answered (Int. 08, 10). In the end, the agency managed to organise the mission, however, how it got there highlighted the weaknesses of an informative agency with no authoritative powers and in a policy sector with low interdependence. 


\section{From agency involvement to leading crisis response: politics matter}

The four agencies studied had to navigate different political environments around the TBCs that favoured or constrained their leadership in the coordination of the responses. Our findings confirmed our expectations: political compromises in the area of banking regulation and food safety made room for the EBA and EFSA to play a leading role in the coordination of the responses. In the case of the ECDC, the agency's weak involvement in the outbreak was compensated by a political environment that eventually opened the scope to organise the mission in Africa. Conversely, the lack of political compromise in the refugee crisis relegated Frontex to a merely technical instrument.

In the banking crisis, the political implications of inaction for the actors involved in the response favoured the EBA's central role. Although the proposal of a deeper integration via a true European banking union initially produced an important political divide between creditor and indebted member states (Gren et al. 2015), the need for trustworthy entities at the EU level that could offer the affected member states technical expertise outweighed the initial disagreements. In this case, the political cost of doing nothing was perceived as much higher for the European Union and for the member states. For the European Union, doing nothing delegitimised their quest for deeper European answers in this crisis while for member states a collapse in the banking system would have had unforeseen economic but also political consequences. In this context, central political actors opened the space up for the EBA, as the European banking supervisor, to streamline the troubled banking systems in the most affected member states (European Commission 2012). The political variable helped expand the agency’s leadership in banking supervision across Europe. 
In the E. coli crisis, the political variable was a determining factor for EFSA to assume a leading role in coordinating the response. The outbreak created important diplomatic tensions as Spanish vegetables were initially blamed by German authorities on carrying the pathogen (El Mundo 2011). This situation generated economic losses as well as fears in the public who avoided eating raw vegetables (El País, 2011). The urgency with which finding the culprit of a transboundary outbreak was perceived favoured the search for European solutions. In this context, the Commission played a central role as it found a political compromise among member states so that EFSA could operate as a crisis manager despite its risk-assessing mandate. The agency was able to fully deploy its resources while receiving full cooperation from the affected member states.

In the Ebola outbreak, the ECDC adopted a discrete role as initial disinterest in the outbreak from central political actors -namely, member states - did not provide incentives for a Europe-wide response. In this vacuum, the Commission attempted to lead the response -via DG ECHO -by providing financial resources (in the form of humanitarian, development and research aid) to the most affected countries in Africa (European Commission 2015) and setting up intersectoral technical boards (where the ECDC was present). Certain member states (e.g. the UK) initially adopted unilateral measures such as screening procedures in ports of entry against the ECDC's advice (Int. 03, 04). However, the situation changed after the outbreak started escalating in 2014, a nurse in a Madrid hospital was infected and the WHO and the US CDC asked the ECDC to participate in an international mission in Africa. For the Commission and the member states, the political consequences of inaction became high enough not to allow a larger European technical response beyond EU borders. Although the ECDC's 
involvement in the response to the outbreak was weak (due to the slow reaction and their dependence on the Commission and member states' resources), its role in the mission contributed to their positioning as a technical benchmark in Ebola management (Interview 02, 03, 04, 05).

In the 2015 refugee crisis, political conflict among central actors, namely the EU and the member states, striped Frontex of an authoritative mandate to coordinate operations as it struggled to acquire material resources. The inability of the EU and the member states to offer coherent responses to the emergency was the outcome of perverse incentives that made of European responses based on solidarity highly unpopular among the national political elites. As Schimmelfennig (2018) explains, governments calculated the political costs of deeper integration in this area while focusing their position in the response to the crisis on the least costly option (unilateral national responses). Examples of this political climate include resorting to restrictive national responses such as the temporary suspension of the Schengen Agreement (e.g. Austria, Denmark, France, Norway and Sweden) or the formation of coalitions among those member states against the EU-supported quota system to redistribute Syrian refugees (Trauner 2016).

\section{Uncovering the emergence of different coordination images}

The combination of the institutional and functional variables provided us with an explanation of different levels of involvement in crisis response. However, only after adding the political variable does it become clear that that involvement drove certain agencies to a leading role in response coordination. By combining our three variables, 
one may observe the emergence of four coordination images that correspond to each of the agencies studied (see table 2 below).

[Table 2 around here]

The first image is the powerful coordinator. This image is represented by the EBA as it enjoyed an authoritative mandate that provided it with the capacity to act on its own. The banking crisis occurred in a strongly interdependent policy sector where political compromise among central actors was deemed as less costly than inaction. The EBA exerted a leading role among national supervisors and EU institutions as it clearly positioned itself as a central tool to counter the risks involved in the banking crisis.

The second image is the powerless coordinator. This is the case of Frontex. Despite having an authoritative mandate in coordinating border control operations, the agency lacked resources that in the end limited its involvement. The low interdependence in the policy sector did not create incentives for the agency's deeper technical involvement in the response. Moreover, the political position of central actors (i.e. member states) and their unilateral responses during the refugee crisis made the agency's coordination irrelevant.

The third image refers to the skilful coordinator. It is illustrated by the EFSA and its role in the E. coli crisis. Despite not having a crisis management mandate, functional and political motivations made the agency central in leading the response. As political conflict among different actors on how to better cope with the outbreak emerged in a policy sector close to the heart of the SEM, the agency was able to position itself in a leading position. Once the Commission conferred authoritative support on it during the 
crisis, the agency erected itself as a technical hub thanks to the expertise accrued over time in food crises in Europe.

The fourth image refers to the intrepid coordinator. It is best represented by the ECDC during the Ebola crisis. The agency tried to offer coordination to cope with the crisis, without having the explicit mandate or the resources to do so, even in the absence of authoritative delegation by the main political actors. In the absence of institutional or functional drivers to increase involvement in the outbreak, the political variable emerged as a powerful element that eventually widened its scope to coordinate the scientific mission in Guinea. However, its weak involvement affected the agency’s coordination capacity.

\section{Conclusion}

Our study sought to disentangle the involvement of EU agencies in different crises affecting their respective policy sectors. To do so, we placed the strength of their involvement at the intersection of the institutional and functional dimensions agencies faced when the crises emerged. From there, we applied a political variable to see if this involvement meant leading the responses to TBCs.

Our expectations seem to be confirmed by our findings to some extent. The formal delegation of authority did not explain on its own the degrees of involvement the agencies had in the crises studied. In fact, the capacity to carry out their mandate in practice seemed to be more important than the formal delegation of authority to agencies. This observation is in line with scholars who warn that the delegation of formal authority to agencies is not the same as having the ability to use this authority in 
practice (Busuioc 2009; Busuioc and Groenleer 2012). This is the case of Frontex, an agency with formal powers in the operational coordination of border management and whose involvement in the refugee crisis is limited. To make sense of the institutional dimension, we need to look at the interdependence among the actors in the policy sector where the agencies operate. Our results strongly support the centrality of this element in the type of involvement agencies had in crisis responses. In fact, those agencies -EBA and EFSA- in policy sectors with high interdependence among their actors enjoyed more involvement than the others.

Leading actions seemed to be an exercise based on the capacity agencies had to fully use the mandate at their disposal and to set themselves up as a hub of specialised knowledge, introducing thoughtful specialised knowledge, response protocols and planning capabilities. The political agreement to have Europe-wide responses to crises emerged as a determining factor in the agencies' leading role. This is clearly the case of the EBA in the banking crisis or EFSA in the E. coli outbreak which became benchmarks in their policy sectors for actors in conflict looking for solutions. Within these cases, it is clear the role that certain actors had in opening up the space so the agencies could exert their leadership. For instance, the Commission’s endorsement was vital for agencies (e.g. EFSA) to assume a more central role in their policy area. These examples confirm previous studies on EU agencies that deemed the Commission a central actor in their working dynamics (Egeberg et al. 2011; Egeberg and Trondal 2017). Conversely, the political disagreement among the member states in the refugee crisis show how these situations weaken agency involvement and their coordinating capacity. In the case of the ECDC, the call on the agency to participate in an 
international mission came after the political conditions changed, favouring a more Europe-wide response to the outbreak.

Agencies saw their leading role reinforced during crises when institutional, functional and political factors allowed them to offer coherence as coordinating actors at different levels in the response. From here, the four coordination images sought to present the extent agencies can truly become, as Boin et al. (2014) claimed, coordination nodes in crisis responses -given their capabilities and constraints. In this multilevel context, EU agencies actually engaged in a balancing act between the expectations in their mandate and what they could effectively achieve.

The acceptance of crises having trans-European value has become the new normal in the European scenario. This conveys the implicit acceptance of more powerful specialised organizations that can take a broader view of the complex, multilevel picture of interactions among different parts of the system for specific policy areas or even issues. The agencification of the EU is still in its infancy as most of the agencies were created after the 2000s. This means that they are still experimenting their capabilities and establishing their policy goals. In any case, our findings show that the ever-more pressing need for European responses to crises may herald a more relevant role for these organisations. Agencies are called to become coordinating nodes of expert knowledge that can bring coherence, and eventually leverage, to the governance of crises in the EU. 


\section{Acknowledgements}

This study was supported by the TransCrisis project (grant number 649484) under the European Union Horizon 2020 programme. We are grateful to the insightful and constructive comments of the three anonymous reviewers and Dr. Ixchel Pérez-Durán. Previous versions of this paper were presented in the panel "The Role of Leadership in EU Politics and Policy-Making: Moving Towards Theoretical Integration and Methodological Cross-Fertilization” at the ECPR Joint Session held in Nicosia (April 2018) and in the workshop “EU Agencies as 'Inbetweeners'? The Relationship between

EU Agencies and Member States” organised by TARN at Maastricht University (December 2019). 


\section{References}

Ansell, C., Boin, A., \& Keller, A. (2010). Managing transboundary crises: Identifying the building blocks of an effective response system. Journal of Contingencies and Crisis Management, 18, 195-207.

Boin, A. \& Ekengren, M. (2009). Preparing for the world risk society: Towards a new security paradigm for the European Union. Journal of Contingencies and Crisis Management, 17, 285-294.

Boin, A., \& Rhinard, M. (2008). 'Managing Transboundary Crises: What Role for the European Union?’ International Studies Review, 10, 1-26.

Boin, A., Busuioc, M., \& Groenleer, M. (2014). 'Building European Union capacity to manage transboundary crises: Network or lead-agency model?' Regulation and governance, 8, 418-436.

Börzel, T. A., \& Risse, T. (2018). From the euro to the Schengen crises: European integration theories, politicization, and identity politics. Journal of European Public Policy, 25, 83-108.

Busuioc, M. (2009). Accountability, Control and Independence. The Case of European Agencies’, European Law Journal, 15, 599-615.

Busuioc, (2013). European Agencies: Law and Practices of Accountability. Oxford: Oxford University Press. 
Busuioc, M. \& Groenleer, M. (2012). Wielders of Supranational Power? The Administrative Behavior of the Heads of European Union Agencies. In M. Busuioc, M. Groenleer, \& J. Trondal (Eds), The Agency Phenomenon in the European Union (pp. ). Manchester: Manchester University Press

Chetail, V., De Bruycker, P., \& Maiani, F. (Eds.). (2016). Reforming the common European asylum system: The new European refugee law. Leiden: Brill.

Christensen, T. \& Lægreid, P. (2006). Agencification and Regulatory Reforms. Autonomy and Regulation: Coping with Agencies in the Modern State. Cheltenham: Edward Elgar Publishing.

Christensen, J., \& Nielsen, V. (2010). Administrative capacity, structural choice and the creation of EU agencies. Journal of European Public Policy, 17, 176-204.

Christensen, T., Danielsen, O.A., Laegreid, P. \& Rykkja, L. (2016). Comparing coordination structures for crisis management in six countries. Public Administration, 94, 316-332.

Coen, D. \& Thatcher, M. (2008). Network Governance and Multilevel Delegation: European Networks of Regulatory Agencies. Journal of Public Policy, 28, 4971.

EBA (2012a). 'The EBA publishes Recommendation and final results of bank recapitalisation plan as part of coordinated measures to restore confidence in the banking sector.' Press release, December 8. Retrieved from: http://www.eba.europa.eu/documents/10180/15971/Press+release+FINALv2.pdf /c9046302-c51d-4c7e-9156-8481db75d036

EBA (2012b). 'Update on the implementation of the capital exercise.' Press release, July 11. Available at: https://www.eba.europa.eu/-/eba-publishes-final-report- 
on-the-recapitalisation-of-european-banks-and-paves-the-way-for-the-transitionto-the-crdiv-framework

Eberlein, B., \& Grande, E. (2005). 'Beyond delegation: transnational regulatory regimes and the EU regulatory state.' Journal of European Public Policy, 12, 89-112.

EFSA (2011a). 'Tracing seeds, in particular fenugreek (Trigonella foenum-graecum) seeds, in relation to the Shiga toxin-producing E. coli (STEC) O104:H4 2011 Outbreaks in Germany and France’' Technical Report, European Food Safety Authority. Retrieved from: http://onlinelibrary.wiley.com/doi/10.2903/sp.efsa.2011.EN-176/epdf

EFSA (2011b). EFSA monitors E. coli outbreak. Press release, 27 May. Retrieved from: https://www.efsa.europa.eu/en/press/news/110527

EFSA (2011c). Scientific Report of EFSA. Shiga toxin-producing E. coli (STEC) 0104:H4 2011 outbreaks in Europe: Taking Stock. EFSA Journal, 9, 2390.

Egeberg, M. \& Trondal, J. (2011). “EU-level agencies: new executive centre formation or vehicles for national control?” Journal of European Public Policy, 18, 868887.

Egeberg, M., \& Trondal, J. (2017). Researching European Union agencies: What have we learnt (and where do we go from here)?. JCMS: Journal of Common Market Studies, 55, 675-690.

El Mundo (2011). España protesta ante la UE por el 'pepinazo,' May 28

El País (2011). Anecoop sufre la histeria desatada en Europa por la crisis del pepino, June 1.

European Commission. (2012). The Financial Sector Adjustment Programme for Spain. Directorate-General for Economic and Financial Affairs. Occasional Papers, 118. 
European Commission. (2015). EU response to the Ebola outbreak in West Africa. July 10. Retrieved from: https://europa.eu/rapid/press-release_MEMO-155339_en.htm

Ferran, E. (2016). The existential search of the European banking authority. European Business Organization Law Review, 17, 285-317.

Frontex (2015a). 'Frontex accepts Greece’s request for rapid border intervention teams.' Press Note, December 10. Retrieved from: https://frontex.europa.eu/mediacentre/news-release/frontex-accepts-greece-s-request-for-rapid-borderintervention-teams-amcPjC

Frontex (2015b). Frontex welcomes pledges to boost operations Triton and Poseidon. Press release, April 23. Retrieved from: https://frontex.europa.eu/mediacentre/news-release/frontex-welcomes-pledges-to-boost-operations-triton-andposeidon-U6vDFW

Genschel, P., \& Jachtenfuchs, M. (2018). From market integration to core state powers: the Eurozone crisis, the refugee crisis and integration theory. Journal of Common Market Studies, 56, 178-196.

Grant, W. (2012). Agricultural Policy, Food Policy, and Communicable Disease Policy. Journal of Health Politics, Policy and Law, 37 (6), 1031-48.

Greer, S. (2012). The European Centre for Disease Prevention and Control: Hub or Hollow Core? Journal of Health Politics, Policy and Law, 37, 1001-30.

Gren, J., Howarth, D., \& Quaglia, L. (2015). Supranational banking supervision in Europe: The construction of a credible watchdog. Journal of Common Market. Studies, 53, 181.

Groenleer, M. (2009). The Autonomy of European Union Agencies: A Comparative Study of Institutional Development. Delft: Eburon Uitgeverij. 
’t Hart, P., Rosenthal, U., \& Kouzmin, A. (1993). Crisis Decision Making: The Centralization Thesis Revisited. Administration and Society, 25, 12-45.

Heims, E. (2016). 'Explaining Coordination between National Regulators in EU Agencies: The Role of Formal and Informal Social Organization.' Public Administration. Doi: 10.1111/padm.1223

Heims, E. (2017). Regulatory co-ordination in the EU: a cross-sector comparison. Journal of European Public Policy, 24, 1116-1134.

Jacobson, P. (2012). The role of networks in the European union public health experience. Journal of Health Politics, Policy and Law, 37, 1049-1055.

Jordan, A., \& Schout, A. (2006). The coordination of the European Union: exploring the capacities of networked governance. Oxford University Press.

Jordana, J. \& Rosas, G. (2019). Central Banks and Banking Regulation: Historical Legacies and Institutional Challenges.In T. Bach \& K. Wegrich. The Blind Spots of Public Bureaucracy and the Politics of Non-Coordination (pp: 195216). Cham: Palgrave.

Jordana, J. \& Triviño-Salazar, J.C. (2019). European Union agencies: a global governance perspective. Revista de Estudios Políticos,185,169-189.

Kelemen, D., \& Tarrant, A. (2011). The Political Foundations of the Eurocracy. West European Politics, 34, 922-947.

Kettl, D. (2003). System under stress: Homeland security and American politics. Washington, DC: CQ Press.

Lavenex, S. (2015). The external face of differentiated integration: third country participation in EU sectoral bodies. Journal of European Public Policy, 22, 836853. 
Levi-Faur, D. (2011). Regulatory Networks and Regulatory Agencification: Towards a Single European Regulatory Space. Journal of European Public Policy, 18, 810829.

Majone, G. (2002). Delegation of regulatory powers in a mixed polity. European Law Journal. 8, 319-339.

Majone, G. (2005). Dilemmas of European Integration, Oxford: Oxford University Press

Martino-Levi, L. (2019). The European Banking Authority: Legal Framework, Operations and Challenges Ahead. Tulane European and Civil Law Forum, 28.

Mathieu, E. (2016). Regulatory delegation in the EU: Networks, committees and agencies. London: Palgrave Macmillan.

Menz, G. (2015). The promise of the principal-agent approach for studying EU migration policy: The case of external migration control. Comparative European Politics, 13, 307-324.

Moloney, N. (2010). EU Financial Market Regulation after the Global Financial Crisis: “More Europe” or More Risks? Common Market Law Review, 47, 1317-1383

Niemann, A., \& Speyer, J. (2018). A Neofunctionalist Perspective on the 'European Refugee Crisis’: The Case of the European Border and Coast Guard. Journal of Common Market Studies, 56, 23-43.

Olsson, S. (2009). Crisis Management in the European Union - Cooperation in the Face of Emergencies. Berlin-Heidelberg: Springer.

Paul, K. (2012). The Europeanisation of Food Safety: A Discourse Analytical Approach. Journal of European Public Policy, 19, 549-566.

Pérez-Durán, I. (2019). Political and stakeholder’s ties in European Union agencies. Journal of European Public Policy, 26, 1-22. 
Permanand, G. \& Vos, E. (2010). EU regulatory agencies and health protection. In: Mossialos, E., Permanand, G., Baeten, R. \& Hervey, T. (eds). Health systems governance in Europe: the role of European Union law and policy (pp.134185). Cambridge, Cambridge University Press.

Peters, G., \& Wright, V. (2001). The National Coordination of European Policy Making. In J. Richardson (ed). European Union: Power and Policy Making. London: Routledge.

Rittberger, B., \& Wonka A. (2013). Agency Governance in the EU. London: Routledge. Rhinard, M. (2009). European cooperation on future crises: toward a public good? Review of policy research, 26, 439-455.

Rhodes, R. (1997). Understanding governance: Policy networks, governance, reflexivity and accountability. Buckingham: Open University Press.

Robinson, T. \& Deluycker, H. (2012). Editorial: EFSA’s Food and Feed Safety Crisis Preparedness and Response. EFSA Journal, 10, 1-5.

Schimmelfennig, F. (2018). European integration (theory) in times of crisis. A comparison of the euro and Schengen crises. Journal of European Public Policy, 25, 969-989.

Thatcher, M. \& Coen, D. (2008). Reshaping European Regulatory Space: An Evolutionary Analysis. West European Politics, 31, 806-836.

Trauner, F. (2016). Asylum Policy: The EU’s “Crises” and the Looming Policy Regime Failure. Journal of European Integration, 38, 311-325.

Trondal, J. \& Peters, B. (2013). 'The Rise of European Administrative Space: Lessons Learned.’ Journal of European Public Policy, 20, 295-307.

van Boetzelaer, K., \& Princen, S. (2012). The Quest for Co-ordination in European Regulatory Networks. Journal of Common Market Studies, 50, 819-836. 
Vos, E. (2000). EU Food Safety Regulation in the Aftermath of the BSE Crisis. Journal of Consumer Policy, 23, 227-55.

Wonka, A. \& Rittberger, B. (2010). Credibility, Complexity and Uncertainty: Explaining the Institutional Independence of 29 EU Agencies. West European Politics, 33, 730-752. 
Table 1. EU agencies' expected involvement in TBCs according to their functional and institutional dimensions

\begin{tabular}{|l|l|l|}
$\begin{array}{r}\text { Institutional: } \\
\text { Legal mandate }\end{array}$ & $\begin{array}{l}\text { Delegation, wider } \\
\text { capabilities }\end{array}$ & $\begin{array}{l}\text { Non-delegation, } \\
\text { narrower capabilities } \\
\text { Nature of policy sector }\end{array}$ \\
\hline High interdependence & Strong involvement & Expansive involvement \\
\hline Low interdependence & Limited involvement & Weak involvement \\
\hline
\end{tabular}


Table 2. Four images of EU agencies' coordination role in TBCs

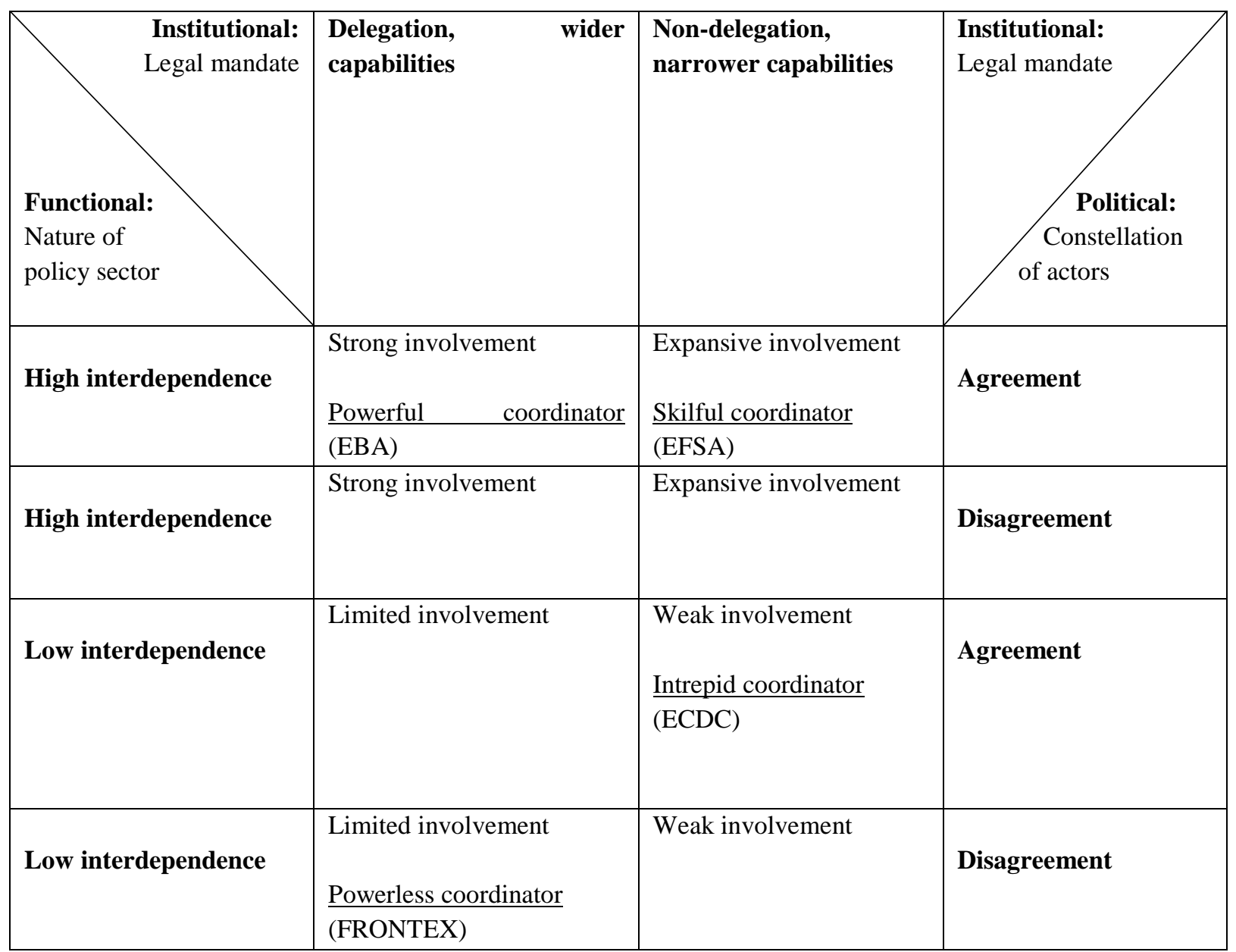




\section{Appendix}

\section{List of interviews}

01. Research officer, EFSA. March 24, 2017.

02. Research officer, EFSA. March 24, 2017.

03. Research officer, EFSA. April 10, 2017,

04. Policy officer, European Commission. April 26, 2017.

05. Policy officer, European Commission. April 28, 2017.

06. Policy officer. European Commission. April 28, 2017.

07. Research officer. ECDC. May 3, 2017.

08. Research officer. ECDC. May 4, 2017.

09. Research officer. ECDC. May 5, 2017

10. Policy officer, ECDC. May 5, 2017

11. Policy officer. Frontex. June 22, 2017.

12. Policy officer, Frontex. June 22, 2017.

13. Research officer. Spanish Ministry of Health. June 26, 2017.

14. Policy officer, EBA. July 19, 2017.

15. Policy officer, EBA. July 19, 2017. 